ACTA THERIOLOGICA

Vol. 33, 8: 87-102, 1988

\title{
Population of the Bank Vole in the Mosaic of Forest Biotopes
}

\author{
Anna BANACH
}

\begin{abstract}
Banach A., 1988: Population of the bank vole in the mosaic of forest bistopes. Acta theriol., 33, 8: 87-102. [With 6 Tables \& 7 Figs.].

The influence of a mosaic of forest habitats on ecological differentiating of a population of Clethrionomys glareolus (Schreber, 1780) was investigated. The study was carried out between 1977 and 1979 close to the town of Mikolajki (Mazurian Lake Region, Poland), in adjoining alderwood, pine wood, willow brushwood and ash thicket areas using the CIMR method. On the basis of the distribution of subsequent catching places one-habitat and multihabitat individuals were distinguished. An analysis of various population parameters indicated that one-habitat individuals from the alderwood, pine wood and willow brushwood differed from one another and formed groups in which certain demographic and density dependent processes had an internal (local) character. Multihabitat individuals occupied areas adjoining the border and displayed the characteristics of population dominants. The density of the multihabitat bank voles per unit of area was constant from summer to autumn and independent of one-habitat bank voles density. An increase in the density of the latter ones brought about a decrease in the areas of home ranges of multihabitat bank voles.

IWarsaw University, Institute of Zoology, Department of Zoology and Ecology, 26/28 Krakowskie Przedmieście Str., 00-927 Warszawa,
\end{abstract} Poland]

\section{INTRODUCTION}

The bank vole, Clethrionomys glareolus (Schreber, 1780), is an eurybiontic species in Poland (e.g. Aulak, 1970; Pucek, 1983), mainly due to its high diet tolerance (e.g. Gębczyńska, 1983). As a result, this species frequently inhabits phytosociologically different forest habitats, co-occurring with various species of small mammals (e.g. Aulak, 1970; Banach et al., 1979; Banach et al., 1980; Malzahn \& Fedyk, 1982; Wołk \& Wołk, 1982; Mazurkiewicz, 1984).

The differentiation in the density of the bank vole population in various habitats testifies to the fact that the environments are not of equal advantages for the population. The dependence of the density of small rodents on environmental conditions is frequently interpreted as dependence upon the food abundance of the environment (e.g. Kalela, 1962; Aulak, 1970; Bock, 1972; Andrzejewski, 1975; Hansson, 1979; Banach et al., 1980). The food conditions of an environment also influence the formation of population structures and the way in which the population of the bank vole functions (e.g. Andrzejewski, 1975; Bujalska, 1975; 
Andrzejewski \& Mazurkiewicz, 1976; Łomnicki, 1978; Mazurkiewicz, 1978; Bujalska, 1979; Gliwicz, 1979).

While analyzing the influence of environmental factors upon the density, structure, and population organization of the bank vole population scientists recently keep on paying more and more attention upon the mosaic character of the environment and variability of its structural and biocenotic components (e.g. Bock, 1972; Bujalska \& Mieszkowska, 1984; Mazurkiewicz, 1984, and others).

The aim of the present study was to assess the influence of the mosaic of forest biotopes upon the ecological differentiation of the bank vole population and the way in which it exploits this habitat.

\section{STUDY AREA, METHODS, AND MATERIAL}

The investigations were conducted in the Mazurian Lake Region (North Poland) in the vicinity of the town of Mikolajki between 1977 and 1979. The 7.17 ha study area was a part of a large (about 3000 ha) forest, in which four phytosociologically different adjacent forest habitats were distinguished (Fig. 1). A detailed characterization of the study area was given in a previous work (Banach, 1987).

Live traps were distributed evenly within the whole 7.17 ha area, in permanent sites which constituted the $15 \times 15 \mathrm{~m}$ grid. There was one trap in each of the site. The animals were lured with oat grain, which was in the traps all the time. The CMR method was applied for analysis.

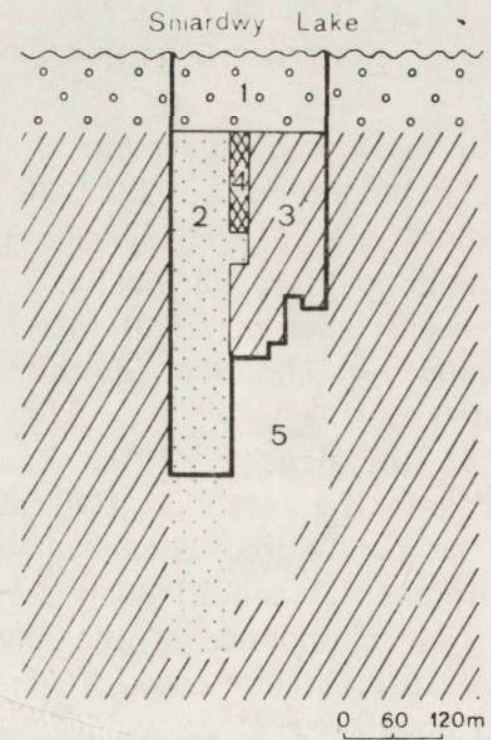

Fig. 1. Scheme of the study area (marked with heavy line), in an area adjoining Lake Sniardwy 1 - willow brushwood, 2 - alderwood, 3 - pine wood, 4 ash thicket, 5 - midforest meadow. 
Ten day series of catches were carried out in the area (in April in spring, in July in summer and in September and October in autumn). In the course of each series the traps were inspected twice a day, in the morning and evening. Each animal found in the traps was investigated with respect of sex, sexual activity and body weight. Those males which hand conspicuously increased testicles, and females with an open vagina, conspicuous signs of gestation, post-copulation plug, or lactating, were considered sexually active.

Home ranges were calculated for animals which were caught more than four times in the course of the ten day series of catches, according to the Mazurkiewicz $(1969,1970,1971)$ method. The degree to which the home ranges overlapped was calculated by means of dividing the total area of all the home ranges by the catching area. The statistical significance between means was calculated using the Student $t$-test (equality of variances was estimated with the Fisher $F$-test. The latter test of significance was also employed to the differences between two ratios.

In the whole study area a total of 1222 bank voles was captured, 601 in the alderwood, 397 in the pinewood, 214 in the willow brushwood and 10 in the ash thicket.

\section{RESULTS}

In the investigated area $C$. glareolus constantly co-occurred with other species of small rodents, but was a more abundant species and constantly inhabited all the biotopes, except a narrow edge of the ash thicket (Fig. 1).

To determine in what way a given individual exploited the mosaic of the biatopes the distribution of points of subsequent catches of all the bank voles were analyzed in each of the ten day series of catches. On this basis those individuals which in a given series of catches were captured only in a single biotope (one-habitat individuals) and individuals which were captured in at least two biotopes (multihabitat individuals) were distinguished. Of the 1222 bank voles recorded in the whole study area 87 (i.e. $7 \%$ ) were multihabitat individuals. One habitat individuals constantly inhabited the alderwood, pine wood and the willow brushwood. In the ash thicket all the bank voles were multihabitat ones.

In order to investigate if the mosaic of habitats may ecologically differentiate individuals in the population of bank voles, one habitat individuals from the alderwood, pine wood and willow brushwood and all multihabitat individuals captured in the whole of the study area were meticulously analyzed.

\subsection{Density Dynamics, Mean Density of Newly Marked Individuals}

The densities $\left(\mathrm{N} \times \mathrm{ha}^{-1}\right)$ of one habitat bank voles were different in different biotopes (except summer 1978) (Fig. 2). The highest of these density differences occurred in both the autumn seasons, i.e. at the peaks of these animals' abundances, a maximum of 59 indiv. $\times$ ha $^{-1}$ in 
the alderwood, 47 indiv. $\times \mathrm{ha}^{-1}$ in the pine wood, and 34 indiv. $\times \mathrm{ha}^{-1}$ in the willow brushwood (Fig. 2). The density dynamics was similar in all the three biotopes. In the alderwood and pine wood the bank vole density values in the same seasons of both the study years were at a similar level (Fig. 2). The mean (for summer and autumn) density of newly-marked individuals in these biotopes was also similar in both study years and amounted to 37.6 indiv. $\times \mathrm{ha}^{-1}$ in the alderwood in the first study year and 33.4 indiv. $\times \mathrm{ha}^{-1}$ in the second study year and to 30.1 and 28.9 indiv. $\times \mathrm{ha}^{-1}$ in the pine wood, respectively. In the willow brushwood the density value recorded in the second study year was

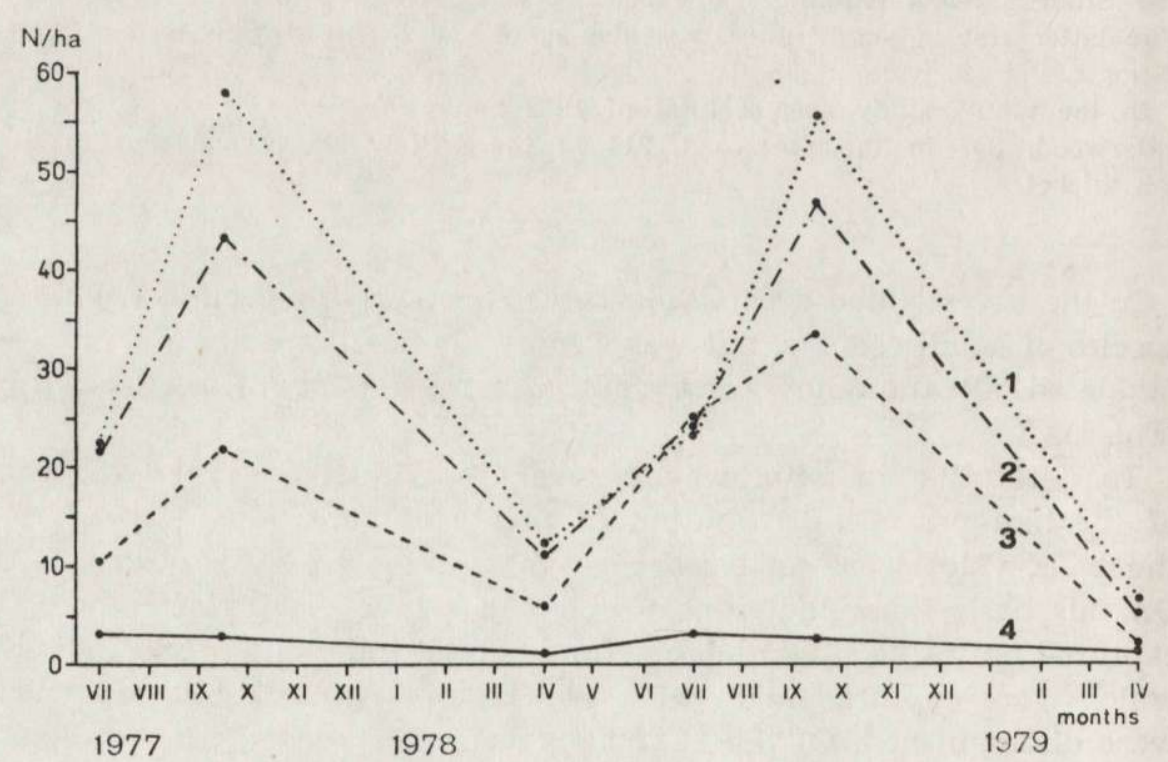

Fig. 2. Density dynamics; one-habitat voles $(1,2,3): 1-$ alderwood, $2-$ pine wood, 3 - willow brushwood; multihabitat voles (4).

1.5 times higher than in the first study year (summer, autumn 1978) (Fig. 2). The mean (for summer and autumn) density of newly-marked individuals in this habitat amounted to 15.2 indiv. $\times \mathrm{ha}^{-1}$ in the first study year and to 26.8 indiv. $\times \mathrm{ha}^{-1}$ in the second study year.

The density of multihabitat bank voles increased from spring to summer (Fig. 2). In the autumn it was slightly lower than in summer. In respective seasons of subsequent study years the density values of multihabitat individuals were very similar (Fig. 2). The mean (for summer and autumn) density of newly marked individuals in this group amounted to 2.5 indiv. $\times \mathrm{ha}^{-1}$ in the first and 2.5 indiv. $\times \mathrm{ha}^{-1}$ in the second study year. 


\subsection{Sex Ratio}

The sex ratio analyzis proved that in all the three groups of onehabitat individuals and in the group of multihabitat individuals the total abundance of males dominated over that of females (Table 1). Only in the alderwood the mean ratio of the abundance of females to that of males differed significantly from $1: 1\left(\chi^{2}\right.$ test, $\left.p=0.01\right)$.

Table 1

Female: male ratio in bank voles from different habitats.

\begin{tabular}{lcccc}
\hline & \multicolumn{3}{c}{ One-habitat voles } & Multihabitat \\
\cline { 2 - 4 } Season & Alderwood & $\begin{array}{c}\text { Pine } \\
\text { wood }\end{array}$ & $\begin{array}{c}\text { Willow } \\
\text { brushwood }\end{array}$ & \\
\hline Summer 1977 & 0.66 & 0.94 & 0.50 & 0.67 \\
Autumn 1977 & 1.53 & 1.24 & 0.84 & 3.50 \\
Spring 1978 & 0.60 & 0.80 & 1.00 & 1.00 \\
Summer 1978 & 0.67 & 0.97 & 0.69 & 0.40 \\
Autumn 1978 & 0.72 & 0.77 & 0.66 & 0.28 \\
Spring 1979 & 0.53 & 0.40 & -1 & -1 \\
Average & 0.78 & 0.85 & 0.78 & 0.73 \\
No. of voles & 540 & 340 & 170 & 87 \\
\hline
\end{tabular}

${ }^{1}$ no males caught in this series.

\subsection{Sexual Activity}

The percentage of sexually active and inactive bank voles both among the one-habitat and multihabitat ones were calculated in subsequent study seasons (Fig. 3). In the breeding season (summer) the highest percentage of sexually active females among one-habitat bank voles was recorded in the alderwood, a lower one in the pine wood, and the lowest one in the willow brushwood, the differences between the related values being statistically significant in the first study year $(0.01<p<0.05$, test of significance of differences between proportions).

In the willow brushwood a significant increase in the percentage of sexually active females and males was recorded in the second study year (summer 1978) in relation to an analogous period of the first study year (summer 1977) $(0.02<p<0.05$, differences between proportions).

The highest percentage of sexually active individuals (especially females) was recorded in the group of multihabitat bank voles (Fig. 3). In the autumn (1977 and 1978) over $60 \%$ of multihabitat females were still sexually active, which proved a long period of their reproduction. In the same period a maximum of $20 \%$ of one-habitat females were active $(0.01<p<0.05$, differences between proportions) (Fig. 3$)$. 

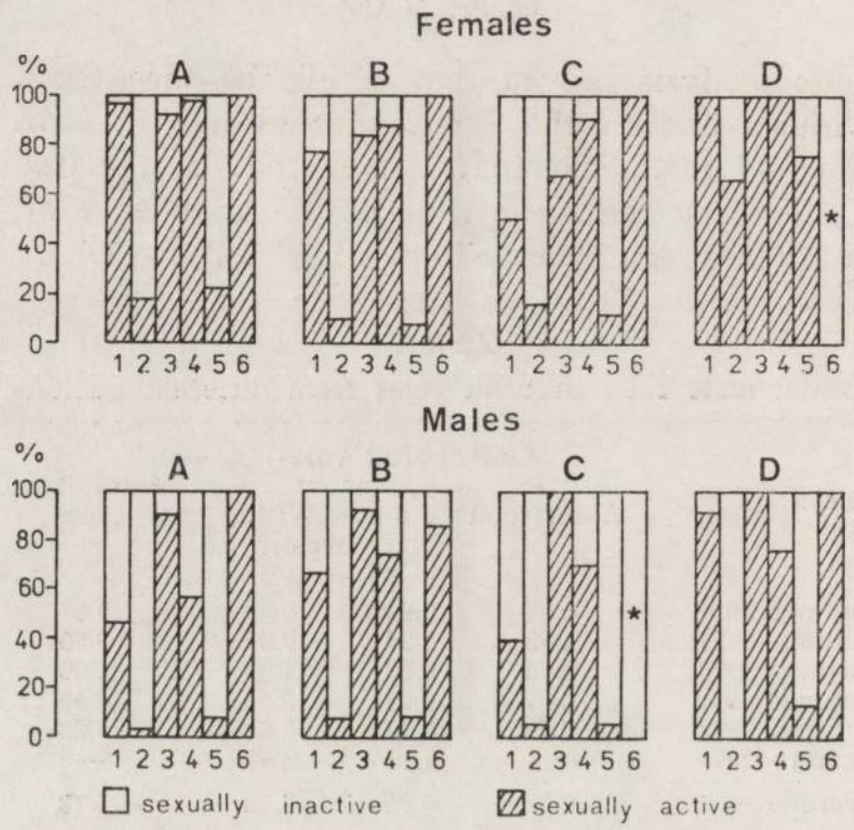

Fig. 3. Percentages of sexually active and inactive female and male individuals. One-habitat voles (A, B, C): A - alderwood, B - pine wood, C - willow brushwood; multihabitat voles (D); $1-$ summer 1977, 2 - autumn 1977, 3 spring $1978,4-$ summer 1978,5 - autumn 1978,6 - spring $1979,^{*}-$ lack lof data.
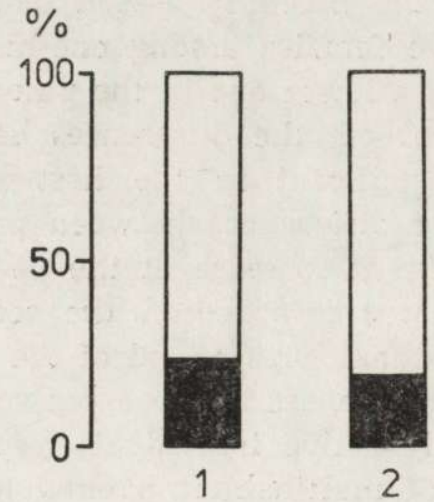

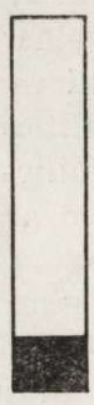

3

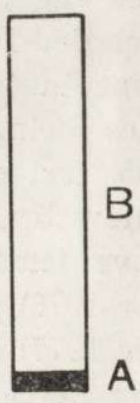

4

Fig. 4. Mean percentage values of newly marked individuals and individuals marked in previous seasons. One-habitat voles $(1,2,3): 1 \rightarrow$ alderwood, $2-$ pine wood, 3 - willow brushwood; multihabitat voles (4): A - individuals marked in previous seasons, B - newly marked individuals. 


\subsection{Survival}

The mean percentages (for the whole study period) of newly marked individuals in the group of multihabitat bank voles and the three groups of one habitat bank voles (Fig. 4) were compared. Newly marked individuals dominated in each of the investigated group; their abundance amounted to over $75 \%$ of all the individuals. This means that only a small percentage of individuals marked in previous seasons survived to the next study season. For the whole study period, an average of only $4.6 \%$ of all multihabitat animals present in a given season survived to the subsequent one. Statistically, significantly higher percentages of individuals surviving from season to season were recorded in the group of one-habitat individuals (an average ranging from $22.6 \%$ to $14.5 \%$ ), the highest percentage of these being that in the alderwood and the lowest that in the willow brushwood $(0.01<p<0.05)$.

\subsection{Body Weight}

A comparison of mean body weight of one-habitat and multihabitat bank voles (without pregnant females) proved that the multihabitat individuals and those inhabiting the alderwood had the highest body weights. Bank voles which inhabited the pine wood and willow brushwood had significantly lower body weights (Student $t$-test, $0.01<p<$ $<0.05$ ) (Table 2).

The body weight distributions of one-habitat bank voles (without the pregnant females) were similar and proved that individuals of various size classes (i.e. from 9 to over $30 \mathrm{~g}$ ) were present in each of the biotopes. In the same season individuals of the same weight classes dominated in all of the biotopes; in summer and autumn those of the $15-20 \mathrm{~g}$ class and in spring those of the $20 \longrightarrow 25 \mathrm{~g}$ class. In all the seasons multihabitat bank voles represented exclusively the $15-20 \mathrm{~g}$ and $20-25 \mathrm{~g}$ classes.

\section{Table 2}

Mean body weights $(\mathrm{g})$ of individuals, * values significantly higher $(0.01<p<0.05)$ than analogous values in the other biotopes.

\begin{tabular}{lccc}
\hline Category and biotope & $N$ & Avg. & $S D$ \\
\hline One-habitat voles: & & & \\
alderwood & 479 & $19.4^{*}$ & 1.3 \\
pine wood & 299 & 18.1 & 1,1 \\
willow brushwood & 150 & 18.4 & 1.0 \\
Multihabitat voles & 79 & $19.3^{*}$ & 0.8 \\
\hline
\end{tabular}




\subsection{Trappability}

The trappability of one-habitat and multihabitat bank voles expressed as a mean number of catches per individual in the ten day series of catches was analyzed. The highest efficiency of catching (for the whole study period) was recorded in the multihabitat bank voles (Table 3). A significantly lower trappability was displayed by one-habitat bank voles (Student $t$-test; $0.01<p<0.02$ ). The mean number of catches of bank voles from the alderwood was also statistically significantly higher than that of the bank voles from the pine wood (Student $t$-test; $0.02<$ $<p<0.05$ ) (Table 3).

Table 3

\begin{tabular}{|c|c|c|c|}
\hline Category and biotope & $N$ & Avg. & $S D$ \\
\hline $\begin{array}{l}\text { One-habitat voles: } \\
\text { alderwood } \\
\text { pine wood } \\
\text { willow brushwood }\end{array}$ & $\begin{array}{l}540 \\
340 \\
170\end{array}$ & $\begin{array}{l}4.9^{* *} \\
4.1^{* *} \\
4.6\end{array}$ & $\begin{array}{l}0.7 \\
0.5 \\
1.3\end{array}$ \\
\hline Multihabitat voles & 87 & $6.6^{*}$ & 0.6 \\
\hline
\end{tabular}

\subsection{Spatial Distribution}

The distribution of the centres of bank vole occurrence areas within the whole study area indicates that the home ranges of one-habitat individuals were randomly distributed in given biotopes, whereas the home ranges of multihabitat individuals were concentrated along the edges of the biotopes (Fig. 5). It was estimated that each multihabitat bank vole crossed the border of each of the adjoining biotope on the average 2.5 times in the course of each of the ten day series of catches.

In all the seasons the mean sizes of the home ranges of multihabitat bank voles were larger than that of one-habitat voles, but statistically significant differences were recorded only in summer and autumn (Table 4) (Student $t$-test; $0.01<p<0.05$ ). In autumn, differences were also recorded in the mean sizes of the home ranges of one-habitat bank voles - home ranges of bank voles from the willow brushwood were significantly higher than those of the bank voles from the alderwood (Table 4) (Student $t$-test, $0.02<p<0.05$ ).

The degree of covering the alderwood and pine wood by home ranges in summer and autumn was higher than 1 , which means that the home ranges overlapped (Table 5). On the average, the highest degree of 
covering the biotope area by home ranges was recorded in the alderwood. In the willow brushwood, in all the seasons this index had values lower than 1 (i.e. home ranges did not overlap) (Table 5).

A

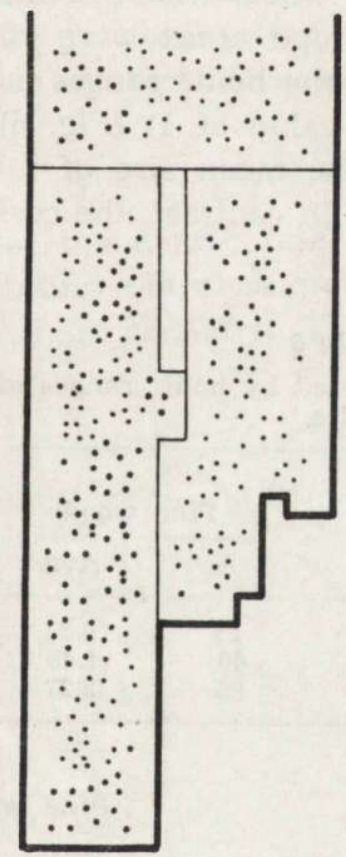

B

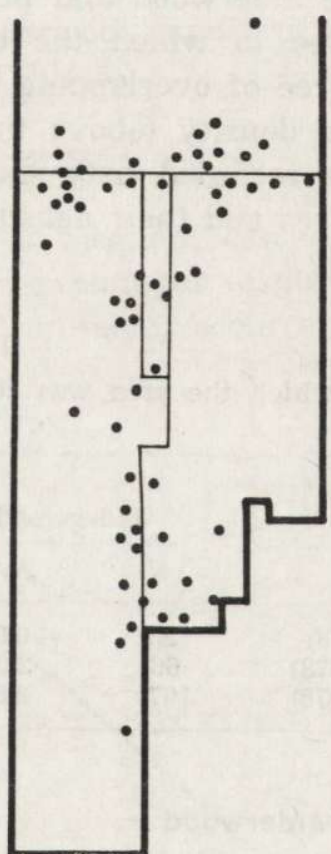

Fig. 5. Distribution of the centres of home ranges in the study area. The description of the study area is presented in Fig. 1. A - one-habitat voles, B - multihabitat voles:

Table 4

Mean home range size $\left(\mathrm{m}^{2}\right)$. * values significantly higher $(0.01<p<0.05)$ than analogous values in the other biotopes, ${ }^{* *}$ significant difference between these values $(0.02<p<0.05)$

\begin{tabular}{|c|c|c|c|c|c|c|c|c|}
\hline \multirow{3}{*}{ Seasons } & \multicolumn{6}{|c|}{ One-habitat voles: } & & \\
\hline & \multicolumn{2}{|c|}{ Alderwood } & \multicolumn{2}{|c|}{ Pine wood } & \multicolumn{2}{|c|}{$\begin{array}{l}\text { Willow } \\
\text { brushwood }\end{array}$} & \multicolumn{2}{|c|}{$\begin{array}{l}\text { Multihabitat } \\
\text { voles }\end{array}$} \\
\hline & $N$ & Avg. & $N$ & Avg. & $N$ & Avg. & $N$ & Avg. \\
\hline $\begin{array}{l}\text { Spring } \\
(1978,1979)\end{array}$ & 26 & 2758 & 15 & 3006 & 5 & 3060 & 8 & 8204 \\
\hline $\begin{array}{l}\text { Summer } \\
(1977,1978)\end{array}$ & 66 & 2195 & 40 & 1706 & 27 & 2150 & 29 & $10136 *$ \\
\hline $\begin{array}{l}\text { Autumn } \\
(1977,1978)\end{array}$ & 167 & $1080^{* *}$ & 85 & 1210 & 45 & 1366 ** & 24 & 2002 * \\
\hline
\end{tabular}


The relationship between the mean size of home ranges and the degree to which a biotope area was covered by home ranges and bank vole density were investigated. No correlation between the above mentioned parameters was recorded in the willow brushwood. No correlation between bank vole density and the mean size of home ranges was recorded in the alderwood and pine wood, whereas in both of the biotopes the degree to which the biotope areas were covered by home ranges and degree of overlapping of the home ranges increased together with bank vole density (above the value of 1) (Fig. 6). No significant correlation. was recorded between the mean size of multihabitat bank voles home ranges and their density. In contrast, the correlation between

Table 5

Mean degree to which the area was covered by home ranges of one-habitat bank voles.

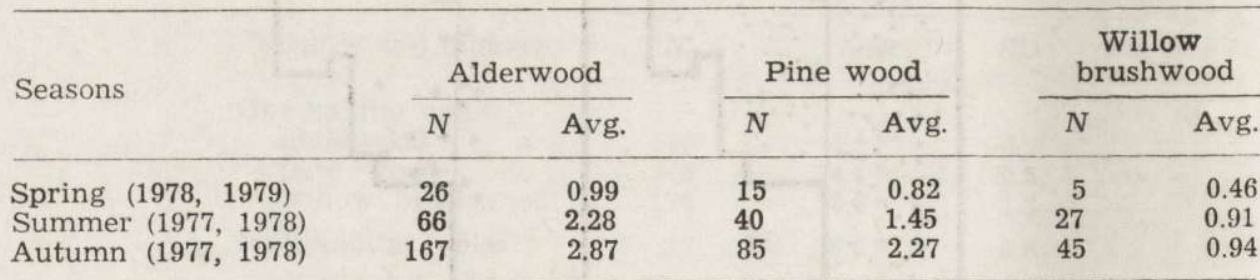
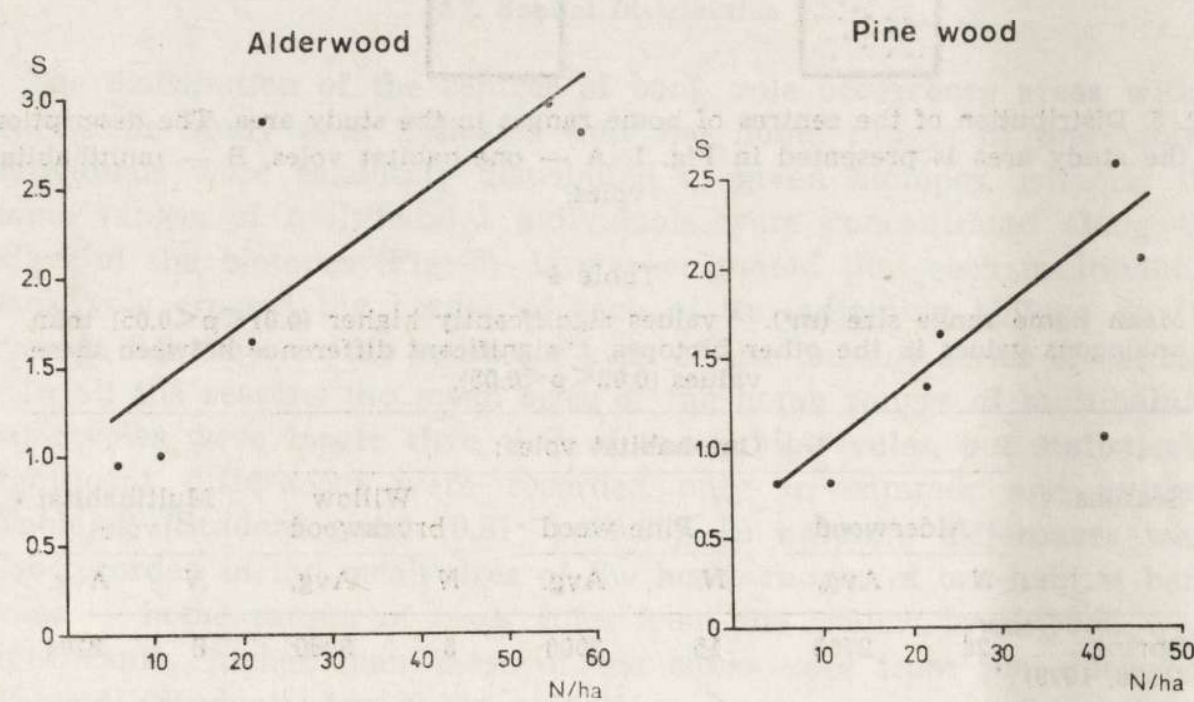

Fig. 6. Correlation between the density of one-habitat voles $\left(\mathrm{N} \cdot \mathrm{ha}^{-1}\right)$ and degree to which the habitat area is covered by home ranges (S). Alderwood: $r=0.822$, $y=0.035 x+1.04$, Pine wood: $r=0.949, y=0.038 x+0.582$. 
the mean home range of multihabitat bank voles and the density of one-habitat voles was negative and significant (Fig. 7).

The centres of one habitat animal home ranges shifted together with the movement of these animals within the biotope. The most significant movement of home range centres from season to season was observed in one-habitat bank voles inhabiting the pine wood (Student $t$-test, $p=0.05$ ). Animals inhabiting the alderwood and willow brushwood moved along much smaller distances (Table 6).

\section{DISCUSSION}

The analysis of the distribution of subsequent catches of individual bank voles inhabiting the mosaic of the biotopes displayed differences in the way they make use of it. The continuous occurrence of the bank

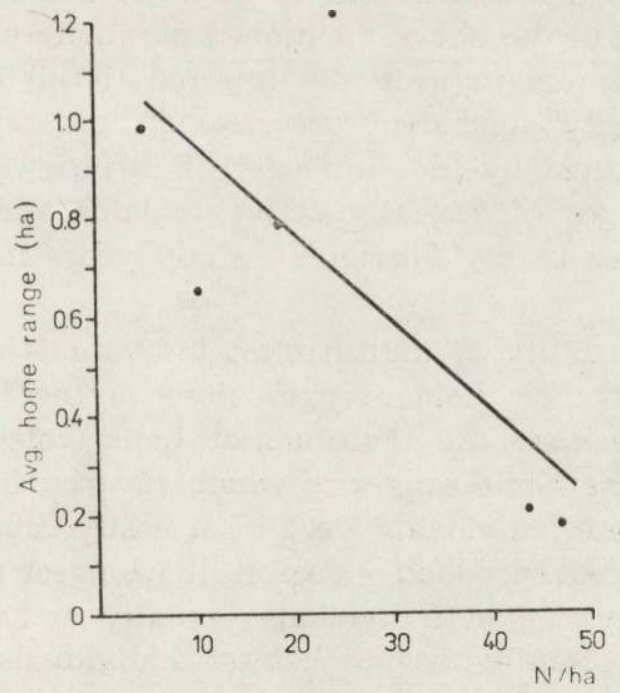

Fig. 7. Correlation between the density of one-habitat voles $\left(\mathrm{N} \cdot \mathrm{ha}^{-1}\right)$ and mean size of home ranges $\left(\mathrm{m}^{2}\right)$ of multihabitat voles. $r=-0.750, y=-0.018 x+1.118$.

Table 6

Mean shifts in the centres of home ranges (m) from season to season. ${ }^{*}$ significant difference between these values $(p=0.05)$.

\begin{tabular}{lrrrr}
\hline Category and biotope & $N$ & & Avg. & $S D$ \\
\cline { 1 - 2 } One-habitat voles: & & & \\
alderwood & 38 & & $25.5^{*}$ & 2.5 \\
$\quad$ pine wood & 17 & $37.5^{*}$ & 8.0 \\
$\quad$ willow brushwood & 7 & 21.0 & 1.2 \\
Multihabitat voles & 2 & 84.0 & 32.5 \\
\hline
\end{tabular}


vole in various biotopes and at the border between them testifies to the continuous way in which the biotopes are inhabited and confirms the eurybiontic character of this species.

A comparison of basic ecological parameters of multihabitat and onehabitat voles from various biotopes indicates the differences which occur between them.

Differences in the autumn density of the one-habitat bank voles in the alderwood, pine wood and willow brushwood prove the various utility of these biotopes for this population. In this system the alderwood was the best biotope (the highest autumn bank vole density, the highest percentage of sexually active females in the reproductive period, the highest density of newly marked individuals, the highest survival rate and highest mean body weight of individuals), and the willow brushwood was the worst one. Differences between the three biotopic groups of the bank voles in the above mentioned parameters and some elements of spatial organization indicate the internal (local) character of demographic and density dependent processes in the investigated biotopes. This is also indicated by the similarity of differences in the bank vole density, percentages of sexually active females and density of newly marked individuals in the subsequent study years in the willow brushwood.

The high trappability of multihabitat individuals and the localization of the centres of their home ranges close to the border between the biotopes indicates that the multihabitat bank voles were mainly the sedentary ones, the home ranges of which covered fragments of at least two biotopes. These individuals were most easily caught, had the largest home ranges in the reproductive season, the longest reproductive period, the highest percentage of individuals sexually active and a high body weight in comparison with one habitat individuals. Thus, this group displayed the characteristics of dominants or individuals of older age groups, which features, are frequently correlated with each other (e.g. Andrzejewski et al., 1967; Gliwicz, 1970; Andrzejewski et al., 1971; Mazurkiewicz, 1971, 1978; Bujalska, 1979; Gliwicz, 1979).

The density of multihabitat individuals was relatively low in the study area from summer to autumn (despite their high sexual activity) and independent of the density of one-habitat individuals. Multihabitat voles reacted to the increase in one-habitat bank vole density by diminishing the size of their home ranges. Thus they settled close to the borders completely exploited the carrying capacity of the border adjoining areas and the length of the border determined their maximal abundance. Thus, they might have constituted a spatial barrier between the one-habitat individuals inhabiting different biotopes. On the other hand, due to an 
almost $100 \%$ exchange of multihabitat individuals from season to seasor and their high sexual activity and large home ranges in the reproductive period, this group might have played an important role in indirect contact and information flow (including genetic information) between one-habitat individuals of various biotopes.

While distinguishing the basic types of strategy of populations inhabiting a mosaic habitat, Rottenbery \& Wiens (1976) pointed out the possibility of pushing out certain categories of individuals from "better" into "worse" habitats. This would result in continuous settling of the mosaic of habitats by the population and strong differentiation of individuals related to its given fragments. This type of strategy would be possible in the bank vole population, assuming that the area of two neighbouring, optimal biotopes, is its best habitat while multihabitat individuals constitute the so-called stem of the population, i.e. they mostly reproduce and thus hand down their characteristics to their. progeny (e.g. Cockburn, 1981).

However, taking into account the relatively low number of multihabitat individuals, another mechanism of differentiation in the population, based upon mutual dependences between individuals also seems possible. According to Andrzejewski (1977) mutual dependences between individuals are the basis of population' existence. They decide about the fact that the population is an "integron" (Petrusewicz, 1978) and comes to an end where these relationships cease (Adamczyk \& Petrusewicz, 1966). Assuming that given individuals in the population leave in the environment signals by means of their presence (in the form of smell, character of burrows and paths, etc), which have informative character for other individuals (Naumov, 1977), the information system created by individuals in the environment and direct contacts between them would constitute a basis for forming a determined internal organization of the population.

Accordingly, one of the reasons of ecological differentiation of a given population of the bank vole may be both the qualitative differentiation of the biotopes (e.g. different informative system) as well as a certain isolation of individuals occupying various biotopes. This isolation would consist not so much in severing of contact between individuals as rather in change in their quality (character) in the zone in which two biotopes meet, due to the presence of multihabitat animals (e.g. dominants).

\section{REFERENCES}

1. Adamczyk K. \& Petrusewicz K., 1966: Dynamics, diversity and intrapopulation differentiation of a free-living population of house mouse. Ekol. pol. A, 14: $725-740$.

2. Andrzejewski R., 1975: Supplementary food and the winter dynamics of bank vole populations. Acta theriol., 20: 23-40. 
3. Andrzejewski R., 1977: Populacje jako system ekologiczny. Wiad. ekol., 23: $3-33$.

4. Andrzejewski R., Fejgin H. \& Liro A., 1971: Trappability of trap-prone and trap-shy bank voles. Acta theriol., 16: 401-408.

5. Andrzejewski R. \& Mazurkiewicz M., 1976: Abundance of food supply and size of bank voles home range. Acta theriol., 21: 237-256.

6. Andrzejewski R., Petrusewicz K. \& Waszkiewicz-Gliwicz J., 1967: The trappability of Clethrionomys glareolus (Schreber, 1780) and other ecological parameters obtained by the CMR capture method. Ekol. pol. A, 15: 709-725.

7. Aulak W., 1970: Small mammal communities of the Białowieża National Park. Acta theriol., 15: 465-515.

7a. Banach A., 1987: Small rodent communities in a complex of forest biotopes. Acta theriol., 32: 229-244.

8. Banach A., Kozakiewicz A., Kozakiewicz M. \& Szulc MI, 1979: Stabilizing role of zoocoenosis enrichment and the ways of animal immigrations into ecosystems. Memorabilia zool., 32: 49-56.

9. Banach A., Kozakiewicz A. \& Kozakiewicz M., 1980: Tentative comparison of small mammal communities in a poor pine stand of various age. Bull. Acad pol. Sci. Cl. II, 28, 1/2: 43-48.

10. Bock E., 1972: Use of forest associations by bank vole population. Acta theriol., 17: 203-219.

11. Bujalska G., 1975: The effect of supplementary food on some parameters in an island population of Clethrionomys glareolus (Schreber, 1780). Bull. Acad. Pol. Sci. Cl. II, 23: 23-28.

12. Bujalska G., 1979: Ekologiczne aspekty rozrodczości nornicy rudej, Clethrionomys glareolus (Schreber, 1780). Wiad. ekol., 25: 25-40.

13. Bujalska G. \& Mieszkowska D., 1984: Distribution of individuals and captures in an island population of the bank vole. Acta theriol., 29: 147-158.

14. Cockburn A., 1981: Population regulation and dispersion of the smoky mouse, Pseudomys fumens. II. Spring decline, breeding success and habitat heterogenity. Austr. J. Ecol., 6: 255-266.

15. Gębczyńska Z., 1983: Feeding habits [In: "Ecology of the bank vole", Ed. K. Petrusewicz]. Acta theriol., 28, Suppl. 1: 40-49.

16. Gliwicz J., 1970: Relation between trappability and age of individuals in a population of bank vole. Acta theriol., 15: 15-23.

17. Gliwicz J., 1979: Struktura wiekowa a organizacja socjalna populacji gryzoni. Wiad. ekol., 25: 9-17.

18. Hansson L., 1979: Condition and diet in relation to habitat in bank voles, Clethrionomys glareolus: population or community approach? Oikos, 33: 55-63.

19. Kalela O., 1962: On the fluctuations in the numbers of arctic and boreal small rodents as a problem of production biology. Ann. Acad. Sci. Fenn., Ser. A. IV. Biol., 66 : $1-38$.

20. Łomnicki A., 1978: Individual differences between animals and the natural regulation of their numbers. J. Anim. Ecol., 47: 461-475.

21. Malzahn E. \& Fedyk S. 1982: Micromammalia of the cultivated Wizna fen. Acta theriol., 27: 25-43.

22. Mazurkiewicz M., 1969: Eliptical modification of the home range pattern. Bull. Acad. pol. Sci., Cl. II, 17: 427-431.

23. Mazurkiewicz M., 1970: Analysis of home range direction based on the catchmark-release method. Bull. Acad. pol. Sci., Cl. II, 19: 465-468.

24. Mazurkiewicz M., 1971: Shape, size and distribution of home ranges of 
Clethrionomys glareolus (Schreber, 1780). Acta theriol., 16: 23-60.

25. Mazurkiewicz M., 1978: Organizacja przestrzenna populacji drobnych gryzoni (na przykladzie nornicy rudej, Clethrionomys glareolus, Schreber, 1780). Wiad. ekol., 24: $377-390$.

26. Mazurkiewicz M., 1984: Population density of small rodents as affected by chosen elements of tree stand structure. Bull. Acad. pol. Sci,, Cl. II, 32: 209-217.

27. Naumov N. O., 1977: Biologičeskie (signalnye) pola i ich značenie v žizni mlekopitajuščich [In: "Uspechy sovremennoj teriologii", Ed. W. E. Sokolov]. Izd. Nauka, Moskva, 93-110.

28. Petrusewicz K., 1978: Osobnik, populacja, gatunek. PWN, Warszawa, 1-384.

29. Pucek M., 1983: Habitat preference [In: "Ecology of the bank vole", Ed. K. Petrusewicz]. Acta theriol., 28, Suppl. 1: 31-40.

30. Rottenbery J. T. \& Wiens J. A., 1976: A method for estimating species dispersion from transect data. Am. Midl. Nat., 94: 64-78.

31. Wolk E. \& Wolk K., 1982: Responses of small mammals to the forest management in the Bialowieża primeval forest. Acta theriol., 27: 45-59.

Received 12 June 1985, Accepted 15 February 1987.

\section{Anna BANACH}

\section{POPULACJA NORNICY RUDEJ W KOMPLEKSIE BIOTOPOW LESNYCH}

\section{Streszczenie}

W pracy podjęto próbę oceny wpływu mozaikowego środowiska leśnego, na ekologiczne różnicowanie się populacji nornicy rudej i na sposób wykorzystania przez nią tego środowiska.

Badania prowadzono na Pojezierzu Mazurskim niedaleko Mikołajek. Teren badań $(7,17$ ha) obejmowal cztery sąsiadujące ze sobą biotopy leśne: łęg olszowy, las sosnowy, zarośla łozowe i młodnik jesionowy (Ryc. 1). Zwierzęta łowiono w pulapki żywolowne w dziesięciodniowych seriach polowów od lata 1977 roku do wiosny 1979 roku (w sumie 6 sezonów badawczych).

Stwierdzono, że nornica ruda była na badanym terenie gatunkiem najbardziej licznym i zamieszkiwała stale w łęgu olszowym, lesie sosnowym i zaroślach lozowych. W młodniku gatunek ten pojawił się okresowo i był mało liczny. $\mathrm{Na}$ podstawie rozmieszczenia punktów kolejnych zlowień wyodrębniono osobniki jednoi wielośrodowiskowe. Stwierdzono, że lęg olszowy, las sosnowy i zarośla lozowe stale zamieszkiwała pewna grupa osobników jednośrodowiskowych. W młodniku (o pow. $0.18 \mathrm{ha}$ ) wszystkie odłowione nornice były osobnikami wielośrodowiskowymi.

Analiza parametrów populacyjnych (zagęszczenia, aktywności płciowej, przeżywalności, średnich ciężarów ciała, średniej liczby złowień przypadającej na jednego osobnika, średniej wielkości areałów osobniczych i stopnia pokrycia powierzchni areałami, średniego przesunięcia centrów areałów osobniczych z sezonu na sezon oraz korelacji pomiędzy zagęszczeniem a średnią wielkością areałów osobniczych i stopniem pokrycia powierzchni areałami osobniczymi) wykazala, że 
osobniki jednośrodowiskowe w lęgu olszowym, lesie sosnowym i zaroślach lozo. wych różnily się między sobą i tworzyły grupy, w których procesy demograficzne i zależne od zagęszczenia mialy charakter wewnętrzny (lokalny) (Table 2, 3, 4, 5, 6, Ryc. 2, 3, 4, 6). Csobniki wielośrodowiskowe, zamieszkujące tereny przygraniczne (Ryc. 5), posiadały cechy dominantów (największy udzial osobników aktywnych plciowo i dlugi okres rozrodu, wysokie średnie ciężary ciała, najwyższa średnia liczba zlowień przypadająca na jednego osobnika, największe areały osobnicze) (Ryc. 3, Table 2, 3, 4). Zagęszczenie nornic wielośrodowiskowych na powierzchni bylo stosunkowo stale od lata do jesieni i niezależne od zagęszczenia nornic jednośrodowiskowych (Ryc. 2). Wzrost zagęszczenia tych ostatnich powodowal zmniejszenie wielkości arealów osobników wielośrodowiskowych (Ryc. 7).

W dyskusji rozważano możliwe mechanizmy prowadzące do różnicowania się populacji nornicy zasiedlającej w sposób ciągły badaną mozaikę biotopów i rolę osobników wielośrodowiskowych w tym procesie. 